Labor at ory cul ture experi ment s to st udy the ef fect of I i gnite hum $c$ aci $d$ fractions on i ron sol ubi I ity and i ron upt ake rates in phyt opl ankt on

\begin{tabular}{|l|l|}
\hline 著者 & $\begin{array}{l}\text { Hasegawa H roshi, Tat e Yousuke, Ogi no Nasashi , } \\
\text { Naki Ter uya, Begum Zi nnat A. , I chi j o } \\
\text { Toshi har u, Rahnan I snai I M M }\end{array}$ \\
\hline $\begin{array}{l}\text { j our nal or } \\
\text { publ i cat i on ti t l e }\end{array}$ & Journal of Appl i ed Phycol ogy \\
\hline vol une & 29 \\
\hline nunber & 2 \\
\hline page r ange & $903-915$ \\
\hline year & $2017-04$ 01 \\
\hline URL & ht t p: //hdl . handl e. net /2297/46941 \\
\hline
\end{tabular}




\section{Laboratory Culture Experiments to Study the Effect of Lignite Humic Acid Fractions on Iron Solubility and Iron Uptake Rates in Phytoplankton}

Hiroshi Hasegawa, ${ }^{*}{ }^{1}$ Yousuke Tate, ${ }^{2}$ Masashi Ogino, ${ }^{2}$ Teruya Maki, ${ }^{1}$ Zinnat A. Begum, ${ }^{3,5}$ Toshiharu Ichijo, ${ }^{4}$ Ismail M. M. Rahman*, 5

${ }^{1}$ Institute of Science and Engineering, Kanazawa University, Kakuma, Kanazawa 920-1192, Japan

${ }^{2}$ Graduate School of Natural Science and Technology, Kanazawa University, Kakuma, Kanazawa 920-1192, Japan

${ }^{3}$ Department of Civil Engineering, Southern University, 739/A Mehedibag Road, Chittagong 4000, Bangladesh

${ }^{4}$ Denka Co., Ltd., Nihonbashi-Muromachi 2-chome, Chuo-ku, Tokyo 103-8338, Japan

${ }^{5}$ Institute of Environmental Radioactivity, Fukushima University, 1 Kanayagawa, Fukushima City, Fukushima 960-1296, Japan

*Author(s) for correspondence.

E-mail: hhiroshi@se.kanazawa-u.ac.jp (HH); immrahman@ipc.fukushima-u.ac.jp or i.m.m.rahman@gmail.com (IMMR)

Tel/ Fax: +81-76-234-4792

Please Cite the article as: $\mathrm{H}$. Hasegawa, Y. Tate, M. Ogino, T. Maki, Z.A. Begum, T. Ichijo and I.M.M. Rahman, Laboratory culture experiments to study the effect of lignite humic acid fractions on iron solubility and iron uptake rates in phytoplankton, Journal of Applied Phycology (In Press), 2017. 


\begin{abstract}
The major fractions of dissolved iron in seawater exist as a complex with organic ligands. A high bioavailability of iron bound to humic acid (HA) compared to the other model ligands, such as desferrioxamine B or ferrichrome, has been reported, which implies the importance of HA to control the geochemical behavior and the transfer of Fe to marine phytoplankton, particularly in estuarine and coastal waters. In the current work, the effect of different HAfractions ( $>100,100-30,30-10,10-5$, and 5-3 kDa), which are extracted from lignite, on the comparative solubility of iron in seawater and the corresponding influence on the iron-uptake and growth rate of the phytoplankton (Prymnesium parvum) has been studied using laboratory cultures. The lower molecular weight (MW) HA fractions, such as 30-10, 10-5 and 5-3 kDa, remained soluble in the simulated seawater medium for a longer time-span compared to the higher MW fractions. The lower MW fractions facilitated higher iron solubility and assisted in achieving a better phytoplankton growth rate. However, a reciprocal impact on phytoplankton growth rates has been observed when the HA concentration increased to a higher range (0.18 to $18 \mathrm{mg}-\mathrm{C} \mathrm{L} \mathrm{L}^{-1}$ ). The highest intracellular Fe uptake in phytoplankton occurred with 30-10 kDa HA in seawater, and the extracellular dissolved Fe concentrations were higher for smaller-sized HA fractions. In a nutshell, our study showed that the controlled addition of lower MW fractions of HA (up to 30-10 kDa) in estuarine waters could ensure the accelerated uptake of Fe in phytoplankton as well as a better growth rate.
\end{abstract}

Keywords: Iron; Phytoplankton; Humic acids; Sea water; bioavailability 


\subsection{Introduction}

In the high-nitrate-low-chlorophyll (HNLC) regions of oceanic waters, in spite of the abundance of plant nutrients, low phytoplankton stocks have been observed, which have been conclusively correlated to the bioavailability of iron (Fe) (Boyd et al. 2012; Martin and Fitzwater 1988). The availability of Fe(III) for biological uptake is correlated to the existence of Fe(III) in the soluble state (Salmon et al. 2006; Sunda and Huntsman 1995; Schlosser et al. 2012) and is controlled by complexation with natural organic chelators (Liu and Millero 2002; Waite 2001; Schlosser and Croot 2009). The iron chelators in seawater have been identified based on different criteria, most notably kinetics (Croot and Heller 2012) and complexation strength (Gledhill and Buck 2012). The humic substances (HS), which constitute 70 to $90 \%$ of the dissolved organic carbon in wetland waters, contribute to keeping iron in a soluble form at both high $\mathrm{pH}$ and high competing ion concentrations in estuarine systems (Rose and Waite 2003; Krachler et al. 2015; Yang and van den Berg 2009).

The source of HS in coastal and oceanic waters (Krachler et al. 2015; Krachler et al. 2010), the importance of HS in complexing iron-species (Batchelli et al. 2010; Bundy et al. 2015; Croot and Heller 2012; Fujii et al. 2010), the potential relationships between HS and iron solubility in the surface ocean (Heller et al. 2013), the impact from coexisting ions, environmental or other factors during the complexation of Fe with HS (Abualhaija et al. 2015; Fang et al. 2015; Laglera et al. 2011), the influence of HS in a phytoplankton bloom in coastal waters (Glover 1978), and the ability of HS to stimulate the growth of coastal phytoplankton in laboratory cultures (Kosakowska et al. 2007; Chen and Wang 2008) have been discussed in the literature.

Piccolo et al. (1997) showed that the complexation between HS and metals increases the corresponding bioavailability for plant uptake. The higher bioavailability of HS-bound Fe(III) to the coastal phytoplankton species compared to that of EDTA-bound Fe(III) (Kuma et al. 1999) or Fe(III) bound to other model ligands, such as desferrioxamine B or ferrichrome (Chen and Wang 2008), has been observed.

The HS content is usually highest in naturally oxidized lignite derivatives, such as leonardite (Peuravuori et al. 2006). The HS isolated from peats and coals have demonstrated beneficial impacts on seed germination, tissue nutrient balance, nutrient uptake and crop yield 
(Tehranifar and Ameri 2012; Adani et al. 1998), which extends the prospect of its use to manufacture organomineral fertilizer at the industrial-scale (Chassapis et al. 2009).

The HS in solution are commonly described as polymers (Ghosh and Schnitzer 1980), and can be segmented into humic (HA) and fulvic (FA) acids based on their solubility in alkalis and acids (Peuravuori et al. 2006). The chemical complexity during HS associations with metals in solution can be presumed due to the supramolecular structure of HS, and the variation in the conformational distribution in humic associations has been observed among the size-fractions separated from lignite HA (Conte et al. 2007).

There have been significant variances in the minimum Fe requirements among marine phytoplankton because coastal eukaryotes need much more Fe than the oceanic ones (Strzepek and Harrison 2004; Allen et al. 2008; Marchetti et al. 2006), which indicates the differences in the Fe-limited conditions in open oceans and estuarine environments (Brand 1991). Prymnesium parvum (a haptophyte) has been used as the model phytoplankton in the current study and is a major component in the geographically widespread marine systems, including temperate and tropical open seas and many coastal areas (Edvardsen and Imai 2006; Carvalho and Granéli 2010). Although there has been an attempt to disassemble the complex concept of iron bioavailability for several phytoplankton-species (Shaked and Lis 2012) or study the release of iron-binding ligands from a marine haptophyte, E. huxleyi (Boye and van den Berg 2000), a similar mechanism has yet to be explored for P. parvum with HA. The objective of the current work was to ascertain the comparative extent of the affinity of lignite-isolated HA fractions toward the iron-species in estuarine environments, which has not been studied before. The relative bioavailability of the complexes of Fe-HA fractions to $P$. parvum was also assessed for the first-time. The focus point of our work is to provide stronger insights into the possible applicability of HS-enriched organomineral fertilizer to facilitate phytoplankton growth in estuaries. 


\subsection{Experimental}

\subsection{Materials}

\subsubsection{Reagents}

$\mathrm{FeCl}_{3} \cdot 6 \mathrm{H}_{2} \mathrm{O}$ from Wako Pure Chemical (Osaka, Japan) and ${ }^{55} \mathrm{FeCl}_{3}$ from Daiichi Pure Chemicals (Tokyo, Japan) were used to prepare the standard Fe and radioactive ${ }^{55} \mathrm{Fe}$ (74 $\mathrm{MBq})$ solutions, respectively. The mixture used for the organic scintillation measurement included 2-(4-tert-butylphenyl)-5-(4-biphenylyl)-1,3,4-oxadiazole from Tokyo Chemical Industry (Tokyo, Japan) and toluene from Wako Pure Chemical (Osaka, Japan). The solution $\mathrm{pH}$ was adjusted using an $\mathrm{HCl}$ or $\mathrm{NaOH}$ solution $\left(1 \mathrm{~mol} \mathrm{~L}^{-1}\right)$ from Kanto Chemical (Tokyo, Japan), and 2-[4-(2-hydroxyethyl)-1-piperazinyl]ethanesulfonic acid (HEPES) from Nacalai Tesque (Kyoto, Japan) was used as a buffer reagent to maintain the solution $\mathrm{pH}$. The $\mathrm{HNO}_{3}$, $\mathrm{H}_{2} \mathrm{SO}_{4}$ and disodium dihydrogen ethylenediamine tetraacetate dihydrate (EDTA) from Dōjindo Laboratories (Kumamoto, Japan) and the PlasmaCAL multi-element solutions in 5\% $\mathrm{HNO}_{3}$ from SCP Science (Québec, Canada) were used during the metal analysis procedures.

\subsubsection{Laboratory wares}

The low-density polyethylene (LDPE) containers and polycarbonate bottles from Nalge Nunc (Rochester, NY), screw-capped LDPE tubes from AS ONE (Osaka, Japan), conical polypropylene centrifuge tubes from Biologix Research (Lenexa, KS), and micropipette tips from Nichiryo (Tokyo, Japan) were used as the laboratory ware. All of the laboratory ware was pre-cleaned by soaking overnight in an alkaline detergent (Scat 20X-PF) from Nacalai Tesque (Kyoto, Japan) and then in an $\mathrm{HCl}$ solution $\left(4 \mathrm{~mol} \mathrm{~L}^{-1}\right)$ from Kanto Chemical (Tokyo, Japan), followed by rinsing with purified water after each of those phases. The purified water with a resistivity $>18.2 \mathrm{M} \Omega \cdot \mathrm{cm}$ was prepared using an Arium Pro water purification system from Sartorius Stedim Biotech GmbH (Göttingen, Germany).

\subsection{Methods}

\subsubsection{Extraction of HA and FA from the lignite and fractionation of HA}

The humic acid cake, which was supplied by Denka Co., Ltd. (Tokyo, Japan), was produced by the acid degradation of lignite (as collected from Berezovsky, Russia) using $\mathrm{HNO}_{3}$. The HA and FA were extracted from the humic acid cake using a modified version of the IHSS 
recommended scheme (Aiken 1985; Thurman and Malcolm 1981). The Supelite DAX-8 column from Sigma-Aldrich (St. Louis, MO), the Amberlite ion-exchange resin from Organo (Tokyo, Japan), and the CE Dialysis Membrane (MWCO 500 1000 Da) from Spectrum (Los Angeles, CA) were used for different steps of the separation process. Centrifugation was conducted using a 5430R centrifuge (Eppendorf AG, Hamburg, Germany) at $7197 \mathrm{~g}\left(5{ }^{\circ} \mathrm{C}\right.$, 20 30 min). The produced HA was subsequently fractionated by applying a tangential-flow ultrafiltration technique using a Vivaflow 200 system from Sartorius Stedim (Surrey, UK). During the process, the permeation coefficient for the HAs with regard to ultrafiltration should be greater than 1 to avoid discrimination in the retention of the solute by the ultrafiltration membrane due to the interactions induced by charge, polarization or shape (Schlosser and Croot 2008). The scheme for the isolation process of HA and FA from lignite and HA fractionation is shown in Fig. 1.

The average molecular weight (AMW) and total organic carbon (TOC) of the fractionated HA and FA are summarized in Table 1. The AMW was determined using an e2695 Alliance High-performance liquid chromatography-size exclusion chromatography (HPLC-SEC) system connected to a PDA Detector 2998 with Empower3 Software from Waters (Milford, MA). The SEC system was equipped with a guard column (Shodex OHpak SB-G, 6.0 i.d. $\times$ $50 \mathrm{~mm}$ ) and Shodex OHpak SB-803-HQ column (8.0 i.d. $\times 300 \mathrm{~mm})$ from Showa Denko KK (Kawasaki, Japan). The eluent system consisted of a phosphate buffer (10 mM $\mathrm{NaH}_{2} \mathrm{PO}_{4} / 10 \mathrm{mM} \mathrm{Na} \mathrm{HPO}_{4} / 25 \%$ acetonitrile in water) at a flow rate of $0.8 \mathrm{~mL} \mathrm{~min}{ }^{-1}$. A TOC-5000A analyzer from Shimadzu (Kyoto, Japan) was used to determine the TOC.

\subsubsection{Three-dimensional fluorescence spectral analysis}

The TOC concentration of the stock solutions of the HA fractions and FA was created at 18 mg-C L $\mathrm{L}^{-1}$ using purified water. The metal content in the stock solutions was less than $1 \%$ for each metal compared to the final total metal concentrations, which indicated minimal impact on the experiments due to the metal contaminants. The solution $\mathrm{pH}$ was adjusted to 8.0 with 1 mol L ${ }^{-1} \mathrm{HCl}$. The solutions (3 mL) were then dispensed to the fluorescence cell $(1 \mathrm{~cm} \times 1$ cm) of a LS55 Fluorescence Spectrophotometer from PerkinElmer LLC (Shelton, CT) to obtain the three-dimensional fluorescence spectra of HS. The Excitation-Emission-Matrix (EEM) spectra were collected with subsequent scanning for emission spectra from 200 to 550 
$\mathrm{nm}$ at $5 \mathrm{~nm}$ increments by varying the excitation wavelength from 200 to $500 \mathrm{~nm}$ at $10 \mathrm{~nm}$ increments at a scan speed of $240 \mathrm{~nm} \mathrm{~min}^{-1}$.

\subsubsection{Fourier-transform infrared (FT-IR) spectral analysis}

Infrared (IR) spectra were recorded in the 4000 to $400 \mathrm{~cm}^{-1}$ frequency domain with a Frontier-Gold FT-IR spectrophotometer (PerkinElmer, Waltham, MA) using samples prepared as $\mathrm{KBr}$ pellets. The $\mathrm{KBr}$ pellets were obtained by pressing, under a reduced pressure, uniformly prepared mixtures of a freeze-dried HS sample $(1 \mathrm{mg})$ and spectrometry grade $\mathrm{KBr}$ (200 mg) being careful to avoid moisture uptake (Stevenson and Goh 1971; Ricca and Severini 1993). The spectra resolution was $8 \mathrm{~cm}^{-1}$.

\subsubsection{Particle size distribution measurement}

The stock solutions of the HA fractions $\left(0.18,1.8\right.$ and 18 mg-C $\left.\mathrm{L}^{-1}\right)$ were added to a modified f/2 culture medium (Morel et al. 1979) using artificial seawater (salinity: 35\%) (Lyman and Fleming 1940) and purified water. Tables S1 and S2 in the supplementary information file show the corresponding compositions of the artificial seawater and modified $f / 2$ culture medium. The solution $\mathrm{pH}$ was maintained at 8.0 using $\mathrm{NaOH}$ or $\mathrm{HCl}(1 \mathrm{M})$. Several sets of mixtures $(15 \mathrm{~mL})$ were prepared, and the homogeneous dispersion of HA in the mixture solutions was ensured via ultrasonic vibration using a 2510J-MT sonicator bath from Yamato Scientific (Tokyo, Japan). The mixtures were allowed to stand for a certain period of time (0, 1.5, 4.5, 6, 12, $48 \mathrm{~h}$, and so on) and subjected to particle size distribution measurements using a LA-950 V2 Laser Scattering Particle Size Analyzer from Horiba (Tokyo, Japan) at room temperature.

\subsubsection{Determination of iron size-speciation and dissolved iron concentration}

The stock solutions of the HA fractions, FA and EDTA $\left(0.18,1.8\right.$ and $\left.18 \mathrm{mg}-\mathrm{C} \mathrm{L}^{-1}\right)$ were added to the modified f/2 medium (60 mL), maintained in a dark place for approximately 24 $\mathrm{h}$, and then spiked with a $1.5 \mu \mathrm{M}$ Fe(III) solution (containing ${ }^{55} \mathrm{Fe}(\mathrm{III}) 3700 \mathrm{kBq} \mathrm{L}{ }^{-1}$ ). The mixture was stirred, and the $\mathrm{pH}$ was adjusted to 8.0 using either $\mathrm{HCl}$ or $\mathrm{NaOH}(1 \mathrm{M})$. A $1 \mathrm{~mL}$ aliquot of the mixture solution $\left(0.18 \mathrm{mg}-\mathrm{C} \mathrm{L}^{-1}\right)$ was collected at a specific time interval ( 0 to $24 \mathrm{~h}$ ) and then filtered using 0.025 and $0.20 \mu \mathrm{m}$ pore-sized Nuclepore membrane filters (Corning, NY) for Fe size fractionation, viz. truly dissolved $\left(\mathrm{Fe}_{\mathrm{sol}}\right)$, colloidal $\left(\mathrm{Fe}_{\mathrm{col}}\right)$ and particulate $\left(\mathrm{Fe}_{\mathrm{par}}\right)$. Each of the filters was washed with $1 \mathrm{~mL}$ of artificial seawater at room 
temperature and soaked in a liquid scintillation solution to facilitate the determination of $\mathrm{Fe}_{\text {col }}$ and $\mathrm{Fe}_{\mathrm{par}}$. Aliquots $(50 \mu \mathrm{L})$ of the unfiltered solutions and $0.025 \mu \mathrm{m}$ filtered solutions were collected to determine the total $\mathrm{Fe}\left(\mathrm{Fe}_{\text {tot }}\right)$ concentration and $\mathrm{Fe}_{\text {sol }}$ in the mixtures at the same time intervals.

Another set of experiments were simultaneously conducted to evaluate the change in the cumulative dissolved iron $\left(\mathrm{Fe}_{\text {dis }}=\mathrm{Fe}_{\text {sol }}+\mathrm{Fe}_{\mathrm{col}}\right)$ concentration with time in the seawater medium. The mixture solutions of the modified $\mathrm{f} / 2$ medium and HA fractions, FA and EDTA (0.18, 1.8 and 18 mg-C L ${ }^{-1}$; $\mathrm{pH} 8.0$ ) were maintained motionless for a specific period (0 to 13 days) in centrifuge tubes, and then the supernatant solution was collected.

To determine the concentrations of $\mathrm{Fe}_{\text {dis }}$, the solutions were allowed to pass through $0.20 \mu \mathrm{m}$ pore-sized polycarbonate filters (Corning, NY), and $50 \mu \mathrm{L}$ of the filtrates were added to the liquid scintillation solutions. The LSC-6101 liquid scintillation counter from Aloka (Tokyo, Japan) was used to execute measurements of ${ }^{55} \mathrm{Fe}$ by ${ }^{3} \mathrm{H}$ mode scintillation counting, and the $\mathrm{Fe}(\mathrm{III}) /{ }^{55} \mathrm{Fe}$ (III) ratios in the sample solutions were used to calculate the $\mathrm{Fe}(\mathrm{III})$ concentration. The detection limit of the $\mathrm{Fe}_{\mathrm{dis}}$ concentration was $10.8 \mathrm{nM}$. The Fe-species was designated as trivalent because the initial spike was carried out using Fe(III), and Fe(II) production due to the photo-reduction under the influence of light being less than $1 \%$ of the $\mathrm{Fe}_{\text {dis }}$ concentration or the detection limit.

A lower Fe concentration $(1.5 \mu \mathrm{M})$ was used for the culture experiments compared to the concentration used $(2.0 \mu \mathrm{M})$ in the laboratory studies for the Fe concentration and the growth of marine micro algae causing red tides (Naito et al. 2008; Naito et al. 2005). A discrete $\mathrm{Fe}_{\text {dis }}$ concentration pattern within the extended range of $(0.092-1.68 \mu \mathrm{M})$ to $(0.0071-0.0094 \mu \mathrm{M})$ based on the salinity zone has been reported for a real estuarine environment, such as San Francisco Bay (Bundy et al. 2015; Flegal et al. 1991). However, the difference was obvious because the elucidation of the natural Fe cycle with HA in estuarine waters was not the objective of our study and the addition of Fe-rich and HA-rich organomineral fertilizer into the system would facilitate an initial increase in the Fe concentration to the $\mu \mathrm{M}$ region followed by a decrease. The HA contents were maintained at a higher ratio than those found in the natural seawater to understand the effect of artificial HA fertilization on iron bioavailability. 
It has been confirmed in earlier works that unchelated-Fe(III) is the dominant species that binds to the cell-surface ligand and is transported across the cell membrane during Fe uptake in marine eukaryotic phytoplankton, while the Fe(II) is only formed as an intermediate species (Shaked and Lis 2012; Shaked et al. 2005; Lis et al. 2015). Due to the high concentration and binding strength of organic ligands compared to inorganic species of Fe, the organic species typically account for $>99 \%$ of the total dissolved Fe in most marine systems. Hence, in the current work, both the $\mathrm{Fe}_{\text {sol }}$ and $\mathrm{Fe}_{\text {col }}$ were considered to be the HAFe(III) in accordance with Morel et al. (2008), and the quantification or differentiation of Fe(III) vs Fe(II), or chelated vs unchelated-Fe, has not been attempted.

\subsubsection{Collection and maintenance of the phytoplankton culture}

The axenic strain of the marine phytoplankton Prymnesium parvum, isolated from Fukuyama Bay, Hiroshima, Japan, was used and the 4',6-diamidino-2-phenylindole test was used to assess and monitor the axenicity. The strain was pre-cultured for 2 weeks in $60 \mathrm{~mL}$ polycarbonate bottles with artificial seawater containing modified f/2 nutrient components in an iron-limited condition $([\mathrm{Fe}] \leq 0.0025 \mu \mathrm{M})$. All of the bottles, tips, and micropipettes that were used during the test, including the modified f/2 medium, were sterilized by autoclaving at $121{ }^{\circ} \mathrm{C}$ for $30 \mathrm{~min}$. The materials were placed on a clean bench and subjected to ultraviolet irradiation for $20 \mathrm{~min}$ for sterilization. The cultures were incubated at $20 \pm 1{ }^{\circ} \mathrm{C}$ using a light intensity of $180 \mu \mathrm{E} \mathrm{m}^{-2} \mathrm{~s}^{-1}$ and a 14:10 h light: dark cycle. The phytoplankton culture was later sub-cultured using the cells logarithmic growth phase following the sterilization protocols described above and were used in the experiment. The autoclave (MLS-3750), clean bench (MCV-711ATS) and incubator chambers (MIR-253) that were used during the phytoplankton culture experiments were all from Sanyo Electric (Osaka, Japan).

\subsubsection{Measurement of phytoplankton growth rate}

The HA fractions, FA and EDTA (0.18, 1.8 and 18 mg-C $\left.\mathrm{L}^{-1}\right)$ solutions in the modified f/2 medium (25 mL) were allowed to stand for $24 \mathrm{~h}$, and then spiked with $1.5 \mu \mathrm{M}$ Fe (pH 8.0). The $18 \mathrm{mg}-\mathrm{C} \mathrm{L}^{-1}$ EDTA was equivalent to $150 \mu \mathrm{mol} \mathrm{L}{ }^{-1}$ EDTA in solution, and the other concentrations of EDTA were prepared accordingly. The modified f/2 medium used to prepare the mixture was subjected to high pressure sterilization followed by ultraviolet irradiation. The phytoplankton $P$. parvum, which was pre-cultured in an iron-limited 
condition ([Fe] $\leq 0.0025 \mu \mathrm{M})$, was inoculated in the experimental culture solution under a laminar air flow condition and retained in a Koitotron 3HN-35DA growth chamber from Koito Industries (Yokohama, Japan) at $20 \pm 1{ }^{\circ} \mathrm{C}$ with a light intensity of $180 \mu \mathrm{E} \mathrm{m} \mathrm{m}^{-2} \mathrm{~s}^{-1}$ under a 14:10 h light: dark cycle. The fluorescence intensity at $680 \mathrm{~nm}$ or absorbance at 540 $\mathrm{nm}$ for each of the medium was measured to determine the temporal changes in the chlorophyll-a concentration or cell density using a TD-700 fluorometer (Turner Designs, Sunnyvale, CA) and a U-2000 spectrophotometer (Hitachi, Tokyo, Japan). The data were used to estimate the phytoplankton growth rate.

\subsubsection{Measurement of the iron uptake rate in the phytoplankton}

The pre-culture of $P$. parvum was cultured in an iron-limited condition ([Fe] $\leq 0.0025 \mu \mathrm{M})$ in $60 \mathrm{~mL}$ of the modified $\mathrm{f} / 2$ medium for 14 days. The $0.18 \mathrm{mg}-\mathrm{C} \mathrm{L}^{-1} \mathrm{HA}$ fractions, FA and EDTA solutions, which were prepared $24 \mathrm{~h}$ before, were then added to the phytoplankton culture solution and spiked with a $1.5 \mu \mathrm{M}$ Fe solution (containing ${ }^{55} \mathrm{Fe} 7400 \mathrm{kBq} \mathrm{L}{ }^{-1}$ ). The solution $\mathrm{pH}$ was maintained at 8.0, and the sterilization or incubation procedures were followed during the above-mentioned experiments and were similar to what was described in the previous section. The culture mediums $(1 \mathrm{~mL})$ were collected later and suction-filtered through a $3.0 \mu \mathrm{m}$ membrane filter. The cells collected on the filters were washed either with a mixed solution of $\mathrm{Ti}(\mathrm{III}) / \mathrm{EDTA} /$ citrate plus seawater $(0.05 \mathrm{M})$ or artificial seawater only to separate the intracellular Fe content or the intracellular and extracellular Fe content together (Hudson and Morel 1989). The ${ }^{55} \mathrm{Fe}$ concentration on the washed filters was measured using the scintillation counting method.

\subsection{Results and discussion}

\subsection{Spectroscopic characterization of the HA fractions}

The characterization of HS in terms of definitive structural or functional properties is challenging due to its heterogeneous and imprecise nature, and a mutual approach combining various spectroscopic and wet-chemical techniques has been suggested (Chen et al. 2002). Fluorescence spectroscopy has been adopted as a classification technique and to distinguish the HS available from different origins (Senesi et al. 1991). The EEM spectra of the HA fractions and FA aqueous solutions can be observed in Fig. 2a. The characteristic ranges for 
the fluorescence intensity for HA has been observed at approximately $260 \mathrm{~nm} / 500 \mathrm{~nm}, 380$ $\mathrm{nm} / 500 \mathrm{~nm}$ and $430 \mathrm{~nm} / 500 \mathrm{~nm}(\mathrm{Ex} / \mathrm{Em})$. The peaks observed at the excitation wavelengths are similar to that of the Inogashira-HA standard (Suzuki et al. 2002) from the Japanese Humic Substances Society (JHSS). The emission band observed at $\sim 500 \mathrm{~nm}$ is reasonably consistent with data published by IHSS and other researchers (Senesi et al. 1989; Chen et al. 2002; Chen et al. 2003). For FA, the peak appeared at an excitation wavelength of 225-260 $\mathrm{nm}$ and $280-320 \mathrm{~nm}$ at a fluorescence intensity of approximately $400-450 \mathrm{~nm}$. The first of the peaks was similar to that observed for the Inogashira-FA standard (Suzuki et al. 2002) from JHSS, while the latter was comparable to that observed in the spectrum of the Suwannee River FA standard (Goldberg and Weiner 1994) from IHSS. Analyzing the EEM data in combination with parallel factor analysis (PARAFAC) has been increasingly adopted for more detailed characterization of organic matter in aquatic ecosystems in recent years (Jaffé et al. 2014). The different humic peaks in the EEMs from the current study were compared to those reported by Heller et al. (2013) who revealed that the iron solubility in the iron replete Atlantic waters was weakly correlated with humic-like components of the dissolved organic matter identified by EEM/PARAFAC analysis.

The short wavelength and high intensities in the fluorescence peaks can be attributed to low aromatic contents, low molecular weight (MW) components, and the presence of a variety of different proton-reactive functional group types, e.g., carboxyl groups and phenolic $\mathrm{OH}$ groups, which were the common characteristics of HA and FA (Senesi et al. 1989; Stevenson 1994). The emission fluorescence of HS in the $440-480 \mathrm{~nm}$ regions might be due to polycondensation between carbonyls and amines, or phenolic structures (Senesi et al. 1989; Senesi et al. 1991; Miano and Senesi 1992; Pullin and Cabaniss 1995). The dissimilarity in the chemical structures between the HA fractions and FA, as confirmed by the peak positions in the EEM spectra, was due to the presence of a higher amount of protonreactive functional groups in FA compared to HA (Christl et al. 2005; Milne et al. 2001). The peak positions in the EEM spectra of the HA fractions suggested that no significant changes occurred in the chemical sites during the process of fractionation based on the average MW distribution. The similarities in the chemical structures among the HA fractions can further be confirmed from the FT-IR spectra, as illustrated in Fig. 2b. 


\subsection{Solubility of the HA fractions in seawater}

The solubility characteristics of the HA size fractions are an important indicator to explain the behavior of and relationship between HS and natural waters (Kipton et al. 1992). The HS molecules, especially HAs, which are regarded either as large polymeric molecules or supramolecular associations of small individual moieties (Piccolo 2001; Sutton and Sposito 2005) are able to form aggregates under certain conditions (Avena and Wilkinson 2002; Engebretson and Von Wandruszka 1997).

The change in the distribution of HA particle sizes in terms of frequency (\%) is shown in the Fig. 3a. The aggregation of HA starts within a very short period (10-20 min) in the medium supplemented with a $>100 \mathrm{kDa} \mathrm{HA}$ fraction, followed by a larger rate of precipitation within a $4.5 \mathrm{~h}$ period. In the case of the 100-30 kDa HA fraction, the aggregation process initiated slowly and a visible precipitate occurred at approximately $12 \mathrm{~h}$. A longer time-leg was required for the formation of aggregates when the $30-10,10-5$ or $5-3$ kDa HA fractions were added to the seawater. Hence, the effect of the MW distribution of HA on their corresponding solubility behavior in seawater was clearly noticeable. The range of molecular weights for the HA fractions, as reported in the current study, were not completely similar to those reported for HS in the literature (Thurman et al. 1982; Perminova et al. 2003), which is attributable to the variation in the source material or experimental designs. It should be noted that the size-fractionation information of HA was used to describe the experimental conditions in the current study, while the average molecular weight (AMW) provides the specific molecular weight of individual fractions (See Table 1). The composition of HA changed to a specific molecular weight range or a smaller one during the fractionation process (Yeats et al. 1990). Therefore, there will be a perceptible decrease in the rate of aggregation with the reduction in the HA size-fractions in the mixtures.

The distribution of particle sizes further confirms that the HA aggregates are mostly 0.1 to 10 $\mu \mathrm{m}$, except for the larger MW fractions of HA (>100 kDa). The HA aggregation process in the solution was usually favored at a lower solution $\mathrm{pH}$ that was attributable to the protonation of functional groups (e.g., carboxylate and phenolate) in HA, which decreased the electrostatic repulsion between molecules and promoted intermolecular $\mathrm{H}$-bond formation (Brigante et al. 2009). However, in the current work, the solution pH was pre-adjusted to a $\mathrm{pH}$ of 8.0 to minimize the above-discussed propensity. Therefore, the other factors that might 
have stimulated the aggregation of cations in the seawater medium were charge neutralization and cation bridge formation (Engebretson and von Wandruszka 1998; vonWandruszka et al. 1997). The assumption was further confirmed when a solution of purified water was supplemented with a >100 kDa HA fraction, and no larger aggregated structure was visible even after $144 \mathrm{~h}$ (Fig. 3b). It was also presumed that the HS and metal ions created an onionlike layered structure in a saline water environment through hydrogen or coordination bonds (Mackey and Zirino 1994) and sank to the sediments when the colloidal structure grew to a certain size (Fig. 3c). Hence, if the larger MW fraction proportion of HA is higher, the rate of HA-aggregation, formation rate of encrusted HS-metal assemblage and corresponding withdrawal of HA from the aquatic environment will be enhanced. It can be noted that the aggregation or precipitation of organic matter and trace elements was also commonly observed in directly estuarine environments (Sholkovitz et al. 1978).

\subsection{Interaction between the HA fractions and iron in seawater}

The iron chemistry within a given body of water depends on its dissolved and particulate forms or size fractions (Bruland and Rue 2001). The majority of the dissolved irons in seawater appeared to be chelated with organic chelators (Rue and Bruland 1997; Boye et al. 2001) and the corresponding complexation equilibria subsequently controlled the dissolved iron concentrations in the oceanic system (Kuma et al. 2003; Johnson et al. 1997). The binding extent between the humic polymers and metal might show a discrepancy depending on the size and configuration of the humic matter, $\mathrm{pH}$ and ionic strength of the solution, the chemical state of the metal itself and the relative abundance of both the metal and HS (Kalinichev and Kirkpatrick 2007). The change in Fe size-speciation, $\mathrm{Fe}_{\text {sol }}, \mathrm{Fe}_{\mathrm{col}}$ and $\mathrm{Fe}_{\mathrm{par}}$, with respect to the HA fractions, FA and EDTA contents $\left(0.18 \mathrm{mg}-\mathrm{C} \mathrm{L}^{-1}\right)$ in the seawater medium within a time span of $24 \mathrm{~h}$ is shown in Fig. 4a. It was observed that the $\mathrm{Fe}_{\text {tot }}$ decreased from the initial concentration of $1.5 \mu \mathrm{M}$ to $1.33-1.44 \mu \mathrm{M}$ over time, which might be due to the adsorption of Fe on the bottle wall (Schlosser et al. 2011) and/or the removal tendency of the Fe-species from the water column as ferric oxyhydroxide (Sholkovitz et al. 1978).

In the absence of any complexing agent in the seawater (the control), the initial $\mathrm{Fe}_{\mathrm{dis}}$ concentration of $1.04 \mu \mathrm{M}$ was reduced significantly to $0.43 \mu \mathrm{M}$ after $2 \mathrm{~h}$ followed by a 
continual decrease to below the detection limit after $24 \mathrm{~h}$. Furthermore, $\mathrm{Fe}_{\text {sol }}$ did not exist in the solution after $2 \mathrm{~h}$ with a notable increase in $\mathrm{Fe}_{\text {par }}$ with time. When the HA fractions or FA was added to the solution, the $\mathrm{Fe}_{\text {dis }}$ decreased to between 0.41 to $0.57 \mu \mathrm{M}$ within $2 \mathrm{~h}$, which was similar to the tendency that was perceived for the control. However, the $\mathrm{Fe}_{\text {dis }}$ remained constant in the range of 0.38 to $0.52 \mu \mathrm{M}$ after $24 \mathrm{~h}$, while a higher $\mathrm{Fe}_{\text {col }}$ ratio than the $\mathrm{Fe}_{\text {sol }}$ was observed, and the $\mathrm{Fe}_{\text {sol }}$ was not exhausted, as was observed in the control conditions. The molar ratios of EDTA to Fe in the spiked solutions were 1:100, 1:10 and 1:1 for 18, 1.8 and $0.18 \mathrm{mg}-\mathrm{C} \mathrm{L}^{-1}$, respectively. The $\mathrm{Fe}_{\text {sol }}$ concentration was significantly higher for the EDTA-spiked solution compared to all of the other chelators. Although the $\mathrm{Fe}_{\text {dis }}$ concentration decreasing trend was observed in the other cases within the first $2 \mathrm{~h}$, it was less prominent $(0.75 \mu \mathrm{M})$ and was sustained to a significantly higher value of $0.68 \mu \mathrm{M}$ even after $24 \mathrm{~h}$. The sustenance of the higher $\mathrm{Fe}_{\text {sol }}$ in the presence of EDTA in the solution can be attributed to the higher formation constant of the EDTA-Fe complexes in solution than many of the known aminopolycarboxylate chelators (Begum et al. 2013; Begum et al. 2012), which also facilitates better bioavailability (Brand 1991; Brand et al. 1983). The HAs with hydroxyl-, phenoxyl-, and carboxyl-reactive groups have a complexing ability with metals (Robertson and Leckie 1999; Pandey et al. 2000), and their facilitatory effect on the solubility of Fe has been presumed. However, the humic matter might create a supramolecular aggregate in the solution consisting of hydrophilic and hydrophobic domains being contiguous to or contained in each other (Piccolo 2002) and might account for the increased ratio of $\mathrm{Fe}_{\mathrm{col}}$ to $\mathrm{Fe}_{\mathrm{par}}$ in the Fe-HS mixtures.

The variations in Fe-speciation were not remarkably conclusive at the 0.18 mg-C L ${ }^{-1} \mathrm{HA}$ fractions, FA and EDTA concentrations during the $24 \mathrm{~h}$ time-span. Hence, the temporal changes in the $\mathrm{Fe}_{\text {dis }}$ contents for a longer time-span (13 days) and varying the concentrations of the complexing agents $\left(0.18,1.8\right.$ and $\left.18 \mathrm{mg}-\mathrm{C} \mathrm{L}^{-1}\right)$ was studied. Any possibility of shaking the culture medium during the whole period was avoided and only the supernatant was collected for analysis. The results are illustrated in Fig. 4b and we can see that the content of $\mathrm{Fe}_{\text {dis }}$ in the seawater medium resembled that of the control after 3 and 6 days for the 0.18 and 1.8 mg-C L ${ }^{-1}$ concentrations of the HA fractions and FA, respectively, while EDTA was an exception in both cases. The distinct effect of different HA fractions and FA on the capability to maintain $\mathrm{Fe}_{\text {dis }}$ in solution was eminent for the chelator concentration dosing of 
18 mg-C L $\mathrm{L}^{-1}$, which indicated the superiority of the HA fractions with a smaller MW than those with a higher MW. It was revealed that the largest nominal molecular weight fractions of HA from lignite have been richer in alkyl and aromatic components, while the smallersized fractions have been composed of carbohydrate-like structures among other compounds and were more polar (Piccolo 2002; Conte et al. 2006), and the observed difference might be caused by that fact.

\subsection{Effect of the HA fractions on the phytoplankton growth}

The logarithmic growth rate curve of the phytoplankton ( $P$. parvum) with the changing concentrations of HS in the seawater medium increased with time up to 16 days and stabilized thereafter during the 30 day experimental tenure (Fig. 5a). A comparative scenario of the $P$. parvum growth rate in the normal scale after a 16 day and 30 day time-span is shown in Fig. 5b. A negative impact on the maximum growth rate of phytoplankton with low MW fractions of HA in solution has been observed with an increase in the chelator concentration from 0.18 to $18 \mathrm{mg}-\mathrm{C} \mathrm{L}^{-1}$ (Fig. 5b). The absorbance values, as measured at 465 $\mathrm{nm}$ for the $0.18,1.8$ and $18 \mathrm{mg}-\mathrm{C} \mathrm{L}^{-1} \mathrm{HA}$ solutions were $0.000,0.002$ and 0.022 , respectively. The values indicated that a decrease in the light intensity occurred with an increase in the HA concentrations in the solution, which might have resulted in the reduced photosynthesis rate. Furthermore, the behavior might be attributed to the reduced Fe uptake of marine phytoplankton communities when an excess concentration of the organic chelator was present compared to the total Fe in the seawater (Hutchins et al. 1999; Wells 1999). The other possibilities might be the complexation of other trace metals resulting in the limitation of growth (e.g., $\mathrm{Cu}, \mathrm{Co}$, and $\mathrm{Zn}$ ) and/or the competition for nutrients with marine bacteria that are stimulated by the addition of HA (Carlsson and Granéli 1993; Carlsson et al. 1995; Granéli et al. 1989).

\subsection{Effect of the HA fractions on the iron uptake rate of the phytoplankton}

In general, the Fe uptake rate by phytoplankton has been related to the computed equilibrium concentration of $\mathrm{Fe}^{3+}$ or, to be more specific, to the concentration of the dissolved inorganic Fe(III) species in the seawater (Anderson and Morel 1982; Hudson and Morel 1990). However, exceptions to the assumption do exist, such as the indirect and/or direct utilization of Fe complexes with organic chelators (e.g., siderophores) that explicitly transport to the 
cells (Hassler et al. 2011; Maldonado and Price 2001), or iron acquisition in phytoplankton cells after an obligatory step of extracellular enzymatic reduction for all of the Fe species (Shaked et al. 2005; Kustka et al. 2007).

Due to their widespread distribution in low-nutrient-open-oceans, $P$. parvum has been used in several oceanographic studies during the last decade (Fistarol et al. 2003; Carvalho and Granéli 2010; James et al. 2011), while the Fe-uptake mechanism still needs to be explored. The terms intra- and extracellular Fe, as used to explain the Fe uptake behavior in P. parvum, have been defined in the earlier work of Hudson and Morel (1989).

In the current study, in the presence of HA fractions and FA in the seawater medium, the extracellular Fe content in P. parvum has been increased 1.3 to 1.8 times (4.09-5.91 fmol cell $^{-1} \mathrm{~h}^{-1}$ ) compared to the control (3.26 fmol cell ${ }^{-1} \mathrm{~h}^{-1}$ ), and a two-fold increase (6.44 fmol cell $^{-1} \mathrm{~h}^{-1}$ ) was observed for EDTA (Table 2). Although bioavailability does not necessarily scale with the solubility of the Fe complexes, the trend, by far, suggested the previous experimental outcome, which confirmed the facilitation of $\mathrm{Fe}_{\mathrm{dis}}$ by the smaller-sized HA fractions (Fig. 4). However, the intracellular Fe uptake rate in P. parvum vs the control (Table 2) indicated a 1.3 to 2.0-fold increase in the Fe content than that of the control $(0.06$ fmol cell ${ }^{-1} \mathrm{~h}^{-1}$ ), and a maximized Fe uptake with a 30-10 kDa HA fraction in the seawater medium. The trend was similar to that of the P. parvum growth rate as shown in Fig. $5 \mathrm{~b}$ for the 0.18 mg-C $\mathrm{L}^{-1} \mathrm{HA}$ in the solution. For FA and EDTA in the seawater medium, the intracellular Fe uptake rate in the P. parvum was low despite a higher extracellular Fe. It might be due to the eukaryotic mechanisms of Fe uptake from organic chelators (e.g., siderophore) binding to $\mathrm{Fe}$, which was mostly involved in cell-surface metalloreductases (Allen et al. 2008; Terzulli and Kosman 2010; Yun et al. 2000). Furthermore, the reduction and subsequent $\mathrm{Fe}$ uptake by oceanic and coastal eukaryotic phytoplankton from $\mathrm{Fe}$ complexes with an organic chelator was generally orders of magnitude lower than that with dissolved inorganic Fe(III) species, especially under Fe-sufficient conditions (Maldonado and Price 2001; Morel et al. 2008). It has also been observed that the organic chelator regulates Fe availability by preventing Fe uptake from an ambient extracellular medium (Iwade et al. 2006; Yoshida et al. 2006). 


\subsection{Conclusion}

The effect of lignite-extracted HA fractions, as segmented based on the MW distribution, in regulating the dissolved iron concentration in seawater as well as to phytoplankton growth was studied in the current work. It was assumed to provide information about the impact of different HA fractions during artificial fertilization to facilitate phytoplankton growth in coastal waters. It has been confirmed that even if the chemical sites among the HA fractions remained unchanged during the fractionation process, the low MW fractions (e.g., 30-10, 105, 5-3 kDa) required more time to become aggregated than the high MW fractions (e.g., >100, 100-30 kDa). The Fe-size speciation study further confirmed that the HA fractions with a smaller MW were capable of maintaining a greater ratio of Fe in the dissolved form than those with a higher MW. The ambient concentration of extracellular Fe was higher in the phytoplankton cultivated in the smaller-sized HA fraction-spiked seawater medium, whereas the intracellular Fe uptake was maximized at the 30-10 kDa HA fraction in the solution. However, the phytoplankton growth rate was hindered even with low MW fractions of HA in the solution if the corresponding concentration of HA increased in the solution. 


\section{Acknowledgment}

The research has partially been supported by the Grants-in-Aid for Scientific Research (15H05118) from the Japan Society for the Promotion of Science. 


\section{References}

Abualhaija MM, Whitby H, van den Berg CMG (2015) Competition between copper and iron for humic ligands in estuarine waters. Mar Chem 172:46-56.

Adani F, Genevini P, Zaccheo P, Zocchi G (1998) The effect of commercial humic acid on tomato plant growth and mineral nutrition. J Plant Nutr 21:561-575.

Aiken GR (1985) Isolation and concentration techniques for aquatic humic substances. In: Aiken GR, McKnight DM, Wershaw RL, MacCarthy P (eds) Humic Substances in Soil, Sediment and Water: Geochemistry and Isolation. Wiley-Interscience, NY.

Allen AE, LaRoche J, Maheswari U, Lommer M, Schauer N, Lopez PJ, Finazzi G, Fernie AR, Bowler C (2008) Whole-cell response of the pennate diatom Phaeodactylum tricornutum to iron starvation. P Natl Acad Sci USA 105:10438-10443.

Anderson MA, Morel FM (1982) The influence of aqueous iron chemistry on the uptake of iron by the coastal diatom Thalassiosira weissflogii. Limnol Oceanogr 27:789-813.

Avena MJ, Wilkinson KJ (2002) Disaggregation kinetics of a peat humic acid: Mechanism and pH effects. Environ Sci Technol 36:5100-5105.

Batchelli S, Muller FLL, Chang K-C, Lee C-L (2010) Evidence for strong but dynamic iron-humic colloidal associations in humic-rich coastal waters. Environ Sci Technol 44:8485-8490.

Begum ZA, Rahman IMM, Hasegawa H (2013) Management of EDTA-containing aqueous effluent: Environmental concerns and remedies. In: Molnar A (ed) EDTA: Synthesis, Uses and Environmental Concerns. Nova Science Publishers, Hauppauge, NY, pp 163-177.

Begum ZA, Rahman IMM, Sawai H, Tate Y, Maki T, Hasegawa H (2012) Stability constants of Fe(III) and $\mathrm{Cr}$ (III) complexes with dl-2-(2-carboxymethyl)nitrilotriacetic acid (GLDA) and 3hydroxy-2,2'-iminodisuccinic acid (HIDS) in aqueous solution. J Chem Eng Data 57:27232732.

Boyd PW, Arrigo KR, Strzepek R, van Dijken GL (2012) Mapping phytoplankton iron utilization: Insights into Southern Ocean supply mechanisms. J Geophys Res-Oceans 117:C06009.

Boye M, van den Berg CMG (2000) Iron availability and the release of iron-complexing ligands by Emiliania huxleyi. Mar Chem 70:277-287.

Boye M, van den Berg CMG, de Jong JTM, Leach H, Croot P, de Baar HJW (2001) Organic complexation of iron in the Southern ocean. Deep-Sea Res PT I 48:1477-1497.

Brand LE (1991) Minimum iron requirements of marine-phytoplankton and the implications for the biogeochemical control of new production. Limnol Oceanogr 36:1756-1771.

Brand LE, Sunda WG, Guillard RRL (1983) Limitation of marine phytoplankton reproductive rates by zinc, manganese, and iron. Limnol Oceanogr 28:1182-1198. 
Brigante M, Zanini G, Avena M (2009) Effect of pH, anions and cations on the dissolution kinetics of humic acid particles. Colloid Surface A 347:180-186.

Bruland KW, Rue EL (2001) Analytical methods for the determination of concentrations and speciation of iron. In: Turner DR, Hunter KA (eds) The Biogeochemistry of Iron in Seawater. IUPAC series on analytical and physical chemistry of environmental systems, vol 7. Wiley, Chichester, England, pp 255-289.

Bundy RM, Abdulla HAN, Hatcher PG, Biller DV, Buck KN, Barbeau KA (2015) Iron-binding ligands and humic substances in the San Francisco Bay estuary and estuarine-influenced shelf regions of coastal California. Mar Chem 173:183-194.

Carlsson P, Granéli E (1993) Availability of humic bound nitrogen for coastal phytoplankton. Estuar Coast Shelf S 36:433-447.

Carlsson P, Granéli E, Tester P, Boni L (1995) Influences of riverine humic substances on bacteria, protozoa, phytoplankton, and copepods in a coastal plankton community. Mar Ecol Prog Ser 127:213-221.

Carvalho WF, Granéli E (2010) Contribution of phagotrophy versus autotrophy to Prymnesium parvum growth under nitrogen and phosphorus sufficiency and deficiency. Harmful Algae 9:105-115.

Chassapis K, Roulia M, Tsirigoti D (2009) Chemistry of metal-humic complexes contained in Megalopolis lignite and potential application in modern organomineral fertilization. Int J Coal Geol 78:288-295.

Chen J, Gu B, LeBoeuf EJ, Pan H, Dai S (2002) Spectroscopic characterization of the structural and functional properties of natural organic matter fractions. Chemosphere 48:59-68.

Chen J, LeBoeuf EJ, Dai S, Gu B (2003) Fluorescence spectroscopic studies of natural organic matter fractions. Chemosphere 50:639-647.

Chen M, Wang WX (2008) Accelerated uptake by phytoplankton of iron bound to humic acids. Aquat Biol 3:155-166.

Christl I, Metzger A, Heidmann I, Kretzschmar R (2005) Effect of humic and fulvic acid concentrations and ionic strength on copper and lead binding. Environ Sci Technol 39:53195326.

Conte P, Spaccini R, Piccolo A (2006) Advanced CPMAS- ${ }^{13} \mathrm{C}$ NMR techniques for molecular characterization of size-separated fractions from a soil humic acid. Anal Bioanal Chem 386:382-390.

Conte P, Spaccini R, Smejkalova D, Nebbioso A, Piccolo A (2007) Spectroscopic and conformational properties of size-fractions acid separated from a lignite humic acid. Chemosphere 69:10321039. 
Croot PL, Heller MI (2012) The importance of kinetics and redox in the biogeochemical cycling of iron in the surface ocean. Front Microbiol 3:219.

Edvardsen B, Imai I (2006) The ecology of harmful flagellates within Prymnesiophyceae and Raphidophyceae. In: Granéli E, Turner JT (eds) Ecology of Harmful Algae. Springer Berlin Heidelberg, Berlin, Heidelberg, pp 67-79.

Engebretson RR, Von Wandruszka R (1997) The effect of molecular size on humic acid associations. Org Geochem 26:759-767.

Engebretson RR, von Wandruszka R (1998) Kinetic aspects of cation-enhanced aggregation in aqueous humic acids. Environ Sci Technol 32:488-493.

Fang K, Yuan D, Zhang L, Feng L, Chen Y, Wang Y (2015) Effect of environmental factors on the complexation of iron and humic acid. J Environ Sci 27:188-196.

Fistarol GO, Legrand C, Graneli E (2003) Allelopathic effect of Prymnesium parvum on a natural plankton community. Mar Ecol Prog Ser 255:115-125.

Flegal AR, Smith GJ, Gill GA, Sanudowilhelmy S, Anderson LCD (1991) Dissolved trace-element cycles in the San-Francisco Bay estuary. Mar Chem 36:329-363.

Fujii M, Rose AL, Waite TD, Omura T (2010) Oxygen and superoxide-mediated redox kinetics of iron complexed by humic substances in coastal seawater. Environ Sci Technol 44:9337-9342.

Ghosh K, Schnitzer M (1980) Macromolecular structures of humic substances. Soil Sci 129:266-276.

Gledhill M, Buck KN (2012) The organic complexation of iron in the marine environment: A review. Front Microbiol 3:69.

Glover HE (1978) Iron in maine coastal waters; seasonal variation and its apparent correlation with a dinoflagellate bloom. Limnol Oceanogr 23:534-537.

Goldberg MC, Weiner ER (1994) Fluorescence measurements of the volume, shape, and fluorophore composition of fulvic acid from the Suwannee River. In: Averett RC, Leenheer JA, Mcknight DM, Thorn KA (eds) Humic Substances in the Suwannee River, Georgia: Interactions, Properties, and Proposed Structures (United States Geological Survey Water-Supply Paper 2373). U.S. Geological Survey, Denver, CO, pp 99-113.

Granéli E, Olsson P, Sundström B, Edler L (1989) In situ studies of the effects of humic acids on dinoflagellates and diatoms. In: Okaichi T, Anderson DM, Nemoto T (eds) Red Tides: Biology, Environmental Science, and Toxicology. Elsevier, NY, pp 209-212.

Hassler CS, Schoemann V, Nichols CM, Butler ECV, Boyd PW (2011) Saccharides enhance iron bioavailability to Southern ocean phytoplankton. P Natl Acad Sci USA 108:1076-1081.

Heller MI, Gaiero DM, Croot PL (2013) Basin scale survey of marine humic fluorescence in the Atlantic: Relationship to iron solubility and $\mathrm{H}_{2} \mathrm{O}_{2}$. Global Biogeochem Cycles 27:88-100.

Hudson RJM, Morel FMM (1989) Distinguishing between extra- and intracellular iron in marine phytoplankton. Limnol Oceanogr 34:1113-1120. 
Hudson RJM, Morel FMM (1990) Iron transport in marine-phytoplankton - kinetics of cellular and medium coordination reactions. Limnol Oceanogr 35:1002-1020.

Hutchins DA, Witter AE, Butler A, Luther GW (1999) Competition among marine phytoplankton for different chelated iron species. Nature 400:858-861.

Iwade S, Kuma K, Isoda Y, Yoshida M, Kudo I, Nishioka J, Suzuki K (2006) Effect of high iron concentrations on iron uptake and growth of a coastal diatom Chaetoceros sociale. Aquat Microb Ecol 43:177-191.

Jaffé R, Cawley KM, Yamashita Y (2014) Applications of excitation emission matrix fluorescence with parallel factor analysis (EEM-PARAFAC) in assessing environmental dynamics of natural dissolved organic matter (DOM) in aquatic environments: A review. In: Rosario-Ortiz F (ed) Advances in the Physicochemical Characterization of Dissolved Organic Matter: Impact on Natural and Engineered Systems, vol 1160. ACS Symposium Series, vol 1160. American Chemical Society, Washington, DC, pp 27-73.

James SV, Valenti TW, Prosser KN, Grover JP, Roelke DL, Brooks BW (2011) Sunlight amelioration of Prymnesium parvum acute toxicity to fish. J Plankton Res 33:265-272.

Johnson KS, Gordon RM, Coale KH (1997) What controls dissolved iron concentrations in the world ocean? Mar Chem 57:137-161.

Kalinichev AG, Kirkpatrick RJ (2007) Molecular dynamics simulation of cationic complexation with natural organic matter. Eur J Soil Sci 58:909-917.

Kipton H, Powell J, Town RM (1992) Solubility and fractionation of humic acid; effect of $\mathrm{pH}$ and ionic medium. Anal Chim Acta 267:47-54.

Kosakowska A, Nędzi M, Pempkowiak J (2007) Responses of the toxic cyanobacterium Microcystis aeruginosa to iron and humic substances. Plant Physiol Bioch 45:365-370.

Krachler R, Krachler RF, von der Kammer F, Süphandag A, Jirsa F, Ayromlou S, Hofmann T, Keppler BK (2010) Relevance of peat-draining rivers for the riverine input of dissolved iron into the ocean. Sci Total Environ 408:2402-2408.

Krachler R, Krachler RF, Wallner G, Hann S, Laux M, Cervantes Recalde MF, Jirsa F, Neubauer E, von der Kammer F, Hofmann T, Keppler BK (2015) River-derived humic substances as iron chelators in seawater. Mar Chem 174:85-93.

Kuma K, Isoda Y, Nakabayashi S (2003) Control on dissolved iron concentrations in deep waters in the western north Pacific: Iron(III) hydroxide solubility. J Geophys Res 108:3289.

Kuma K, Tanaka J, Matsunaga K (1999) Effect of natural and synthetic organic-Fe(III) complexes in an estuarine mixing model on iron uptake and growth of a coastal marine diatom, Chaetoceros sociale. Mar Biol 134:761-769.

Kustka AB, Allen AE, Morel FMM (2007) Sequence analysis and transcriptional regulation of iron acquisition genes in two marine diatoms. J Phycol 43:715-729. 
Laglera LM, Battaglia G, van den Berg CMG (2011) Effect of humic substances on the iron speciation in natural waters by CLE/CSV. Mar Chem 127:134-143.

Lis H, Shaked Y, Kranzler C, Keren N, Morel FMM (2015) Iron bioavailability to phytoplankton: an empirical approach. ISME J 9:1003-1013.

Liu X, Millero FJ (2002) The solubility of iron in seawater. Mar Chem 77:43-54.

Lyman J, Fleming R (1940) Composition of sea water. J Mar Res 3:134-146.

Mackey DJ, Zirino A (1994) Comments on trace metal speciation in seawater or do "onions" grow in the sea? Anal Chim Acta 284:635-647.

Maldonado MT, Price NM (2001) Reduction and transport of organically bound iron by Thalassiosira oceanica (Bacillariophyceae). J Phycol 37:298-309.

Marchetti A, Sherry ND, Kiyosawa H, Tsuda A, Harrison PJ (2006) Phytoplankton processes during a mesoscale iron enrichment in the NE subarctic Pacific: Part I - Biomass and assemblage. Deep-Sea Res Pt II 53:2095-2113.

Martin JH, Fitzwater SE (1988) Iron deficiency limits phytoplankton growth in the north-east Pacific subarctic. Nature 331:341-343.

Miano TM, Senesi N (1992) Synchronous excitation fluorescence spectroscopy applied to soil humic substances chemistry. Sci Total Environ 117-118:41-51.

Milne CJ, Kinniburgh DG, Tipping E (2001) Generic NICA-Donnan model parameters for proton binding by humic substances. Environ Sci Technol 35:2049-2059.

Morel FMM, Kustka AB, Shaked Y (2008) The role of unchelated Fe in the iron nutrition of phytoplankton. Limnol Oceanogr 53:400-404.

Morel FMM, Rueter JG, Anderson DM, Guillard RRL (1979) Aquil: A chemically defined phytoplankton culture medium for trace metal studies. J Phycol 15:135-141.

Naito K, Imai I, Nakahara H (2008) Complexation of iron by microbial siderophores and effects of iron chelates on the growth of marine microalgae causing red tides. Phycol Res 56:58-67.

Naito K, Matsui M, Imai I (2005) Ability of marine eukaryotic red tide microalgae to utilize insoluble iron. Harmful Algae 4:1021-1032.

Pandey AK, Pandey SD, Misra V (2000) Stability constants of metal-humic acid complexes and its role in environmental detoxification. Ecotoxicol Environ Saf 47:195-200.

Perminova IV, Frimmel FH, Kudryavtsev AV, Kulikova NA, Abbt-Braun G, Hesse S, Petrosyan VS (2003) Molecular weight characteristics of humic substances from different environments as determined by size exclusion chromatography and their statistical evaluation. Environ Sci Technol 37:2477-2485.

Peuravuori J, Žbánková P, Pihlaja K (2006) Aspects of structural features in lignite and lignite humic acids. Fuel Process Technol 87:829-839.

Piccolo A (2001) The supramolecular structure of humic substances. Soil Sci 166:810-832. 
Piccolo A (2002) The supramolecular structure of humic substances: A novel understanding of humus chemistry and implications in soil science. In: Sparks DL (ed) Advances in Agronomy, vol 75. Academic Press, San Diego, CA, pp 57-134.

Piccolo A, Pietramellara G, Mbagwu JSC (1997) Use of humic substances as soil conditioners to increase aggregate stability. Geoderma 75:267-277.

Pullin MJ, Cabaniss SE (1995) Rank analysis of the pH-dependent synchronous fluorescence spectra of six standard humic substances. Environ Sci Technol 29:1460-1467.

Ricca G, Severini F (1993) Structural investigations of humic substances by IR-FT, ${ }^{13} \mathrm{C}-\mathrm{NMR}$ spectroscopy and comparison with a maleic oligomer of known structure. Geoderma 58:233244.

Robertson AP, Leckie JO (1999) Acid/base, copper binding, and $\mathrm{Cu}^{2+} / \mathrm{H}^{+}$exchange properties of a soil humic acid, an experimental and modeling study. Environ Sci Technol 33:786-795.

Rose AL, Waite TD (2003) Kinetics of iron complexation by dissolved natural organic matter in coastal waters. Mar Chem 84:85-103.

Rue EL, Bruland KW (1997) The role of organic complexation on ambient iron chemistry in the equatorial Pacific Ocean and the response of a mesoscale iron addition experiment. Limnol Oceanogr 42:901-910.

Salmon TP, Rose AL, Neilan BA, Waite TD (2006) The FeL model of iron acquisition: Nondissociative reduction of ferric complexes in the marine environment. Limnol Oceanogr 51:1744-1754.

Schlosser C, Croot PL (2008) Application of cross-flow filtration for determining the solubility of iron species in open ocean seawater. Limnol Oceanogr Methods 6:630-642.

Schlosser C, Croot PL (2009) Controls on seawater Fe(III) solubility in the Mauritanian upwelling zone. Geophys Res Lett 36:L18606.

Schlosser C, De La Rocha CL, Croot PL (2011) Effects of iron surface adsorption and sample handling on iron solubility measurements. Mar Chem 127:48-55.

Schlosser C, De La Rocha CL, Streu P, Croot PL (2012) Solubility of iron in the Southern ocean. Limnol Oceanogr 57:684-697.

Senesi N, Miano TM, Provenzano MR, Brunetti G (1989) Spectroscopic and compositional comparative characterization of I.H.S.S. reference and standard fulvic and humic acids of various origin. Sci Total Environ 81-82:143-156.

Senesi N, Miano TM, Provenzano MR, Brunetti G (1991) Characterization, differentiation, and classification of humic substances by fluorescence spectroscopy. Soil Sci 152:259-271.

Shaked Y, Kustka AB, Morel FMM (2005) A general kinetic model for iron acquisition by eukaryotic phytoplankton. Limnol Oceanogr 50:872-882.

Shaked Y, Lis H (2012) Disassembling iron availability to phytoplankton. Front Microbiol 3:123. 
Sholkovitz ER, Boyle EA, Price NB (1978) The removal of dissolved humic acids and iron during estuarine mixing. Earth Planet Sci Lett 40:130-136.

Stevenson FJ (1994) Humus Chemistry: Genesis, Composition, Reactions. John Wiley \& Sons, NY.

Stevenson FJ, Goh KM (1971) Infrared spectra of humic acids and related substances. Geochim Cosmochim Ac 35:471-483.

Strzepek RF, Harrison PJ (2004) Photosynthetic architecture differs in coastal and oceanic diatoms. Nature 431:689-692.

Sunda WG, Huntsman SA (1995) Iron uptake and growth limitation in oceanic and coastal phytoplankton. Mar Chem 50:189-206.

Sutton R, Sposito G (2005) Molecular structure in soil humic substances: The new view. Environ Sci Technol 39:9009-9015.

Suzuki Y, Yamaguchi Y, Suzuki S, Hirata S, Aihara M, Hiraki K (2002) Characteristics of aquatic humic substances in natural waters by synchronous and derivative synchronous fluorescence spectrum. Anal Sci 17icas:i1605-i1608.

Tehranifar A, Ameri A (2012) Effect of humic acid on nutrient uptake and physiological characteristic Fragaria ananassa var: Camarosa. J Biol Environ Sci 6:77-79.

Terzulli A, Kosman DJ (2010) Analysis of the high-affinity iron uptake system at the Chlamydomonas reinhardtii plasma membrane. Eukaryot Cell 9:815-826.

Thurman EM, Malcolm RL (1981) Preparative isolation of aquatic humic substances. Environ Sci Technol 15:463-466.

Thurman EM, Wershaw RL, Malcolm RL, Pinckney DJ (1982) Molecular size of aquatic humic substances. Org Geochem 4:27-35.

vonWandruszka R, Ragle C, Engebretson R (1997) The role of selected cations in the formation of pseudomicelles in aqueous humic acid. Talanta 44:805-809.

Waite TD (2001) Thermodynamics of the iron system in seawater. In: Turner DR, Hunter KA (eds) The Biogeochemistry of Iron in Seawater. IUPAC series on analytical and physical chemistry of environmental systems, vol 7. Wiley, Chichester, England, pp 291-342.

Wells ML (1999) Manipulating iron availability in nearshore waters. Limnol Oceanogr 44:1002-1008.

Yang RJ, van den Berg CMG (2009) Metal Complexation by Humic Substances in Seawater. Environ Sci Technol 43:7192-7197.

Yeats PA, Strain PM, Whitehouse BG (1990) Cross-flow filtration of colloids from aquatic environments. Limnol Oceanogr 35:1368-1375.

Yoshida M, Kuma K, Iwade S, Isoda Y, Takata H, Yamada M (2006) Effect of aging time on the availability of freshly precipitated ferric hydroxide to coastal marine diatoms. Mar Biol 149:379-392. 
Yun C-W, Ferea T, Rashford J, Ardon O, Brown PO, Botstein D, Kaplan J, Philpott CC (2000) Desferrioxamine-mediated iron uptake in Saccharomyces cerevisiae: Evidence for two pathways of iron uptake. J Biol Chem 275:10709-10715. 
Table 1: Average molecular weight (AMW) and total organic carbon (TOC) of humic substances extracted from lignite (HA, Humic acid; FA, Fulvic acid).

\begin{tabular}{lll}
\hline Size fraction & $\begin{array}{l}\text { AMW* } \\
{[\mathrm{Da}]}\end{array}$ & $\begin{array}{l}\text { TOC } \\
{\left[\mathrm{mg} \mathrm{L}^{-1}\right]}\end{array}$ \\
\hline HA $(>100 \mathrm{kDa})$ & 4300 & 2600 \\
HA $(100-30 \mathrm{kDa})$ & 2700 & 1900 \\
HA (30-10 kDa) & 2000 & 880 \\
HA (10-5 kDa) & 1200 & 2000 \\
HA (5-3 kDa) & 900 & 1700 \\
FA & 540 & 250 \\
\hline
\end{tabular}

* With reference to the sodium polystyrenesulfonate markers. 
Table 2: The effect of HA fractions on the iron uptake behavior in the phytoplankton cells ( $P$. parvum) in reference to the control, FA and EDTA (HA, Humic acid; FA, Fulvic acid; EDTA, Ethylenediaminetetraacetic acid) ( $n=3)$.

\begin{tabular}{lllll}
\hline Medium & \multicolumn{2}{l}{$\begin{array}{l}\text { Extracellular Fe uptake rate } \\
\left(\mathrm{fmol} \mathrm{cell} \mathrm{h}^{-1}\right)\end{array}$} & \multicolumn{2}{l}{$\begin{array}{l}\text { Intracellular Fe uptake rate } \\
\left(\mathrm{fmol} \mathrm{cell} \mathrm{H}^{-1} \mathrm{~h}^{-1}\right)\end{array}$} \\
\cline { 2 - 5 } & Mean & SD & Mean & SD \\
\hline Control & 3.26 & 1.09 & 0.06 & 0.03 \\
HA (>100 kDa) & 4.09 & 2.10 & 0.10 & 0.02 \\
HA (100-30 kDa) & 5.46 & 0.67 & 0.12 & 0.02 \\
HA (30-10 kDa) & 5.73 & 1.07 & 0.16 & 0.02 \\
HA (10-5 kDa) & 5.75 & 1.40 & 0.12 & 0.05 \\
HA (5-3 kDa) & 5.15 & 0.80 & 0.11 & 0.03 \\
FA & 5.91 & 1.11 & 0.09 & 0.03 \\
EDTA & 6.44 & 0.69 & 0.09 & 0.02 \\
\hline
\end{tabular}




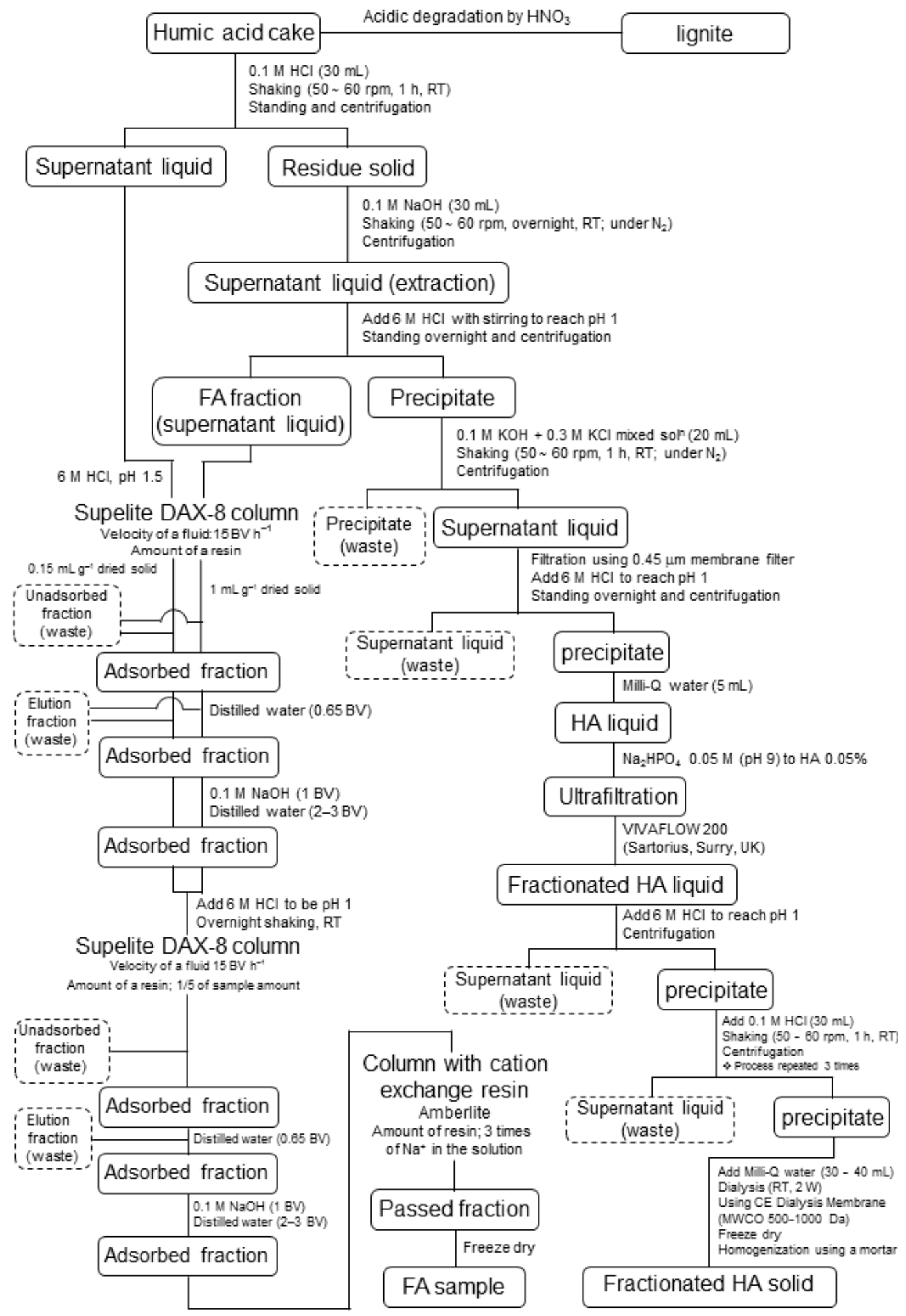

Figure 1: Flow diagram of the isolation process of HA and FA from lignite, and HA fractionation (BV, Bed Volume; RT, Room Temperature $\left(25 \pm 2{ }^{\circ} \mathrm{C}\right)$; Centrifugation condition, $\left.7197 \mathrm{~g}, 5^{\circ} \mathrm{C}, 20 \mathrm{~min}\right)$. 
(a) Excitation-Emission-Matrix Spectra
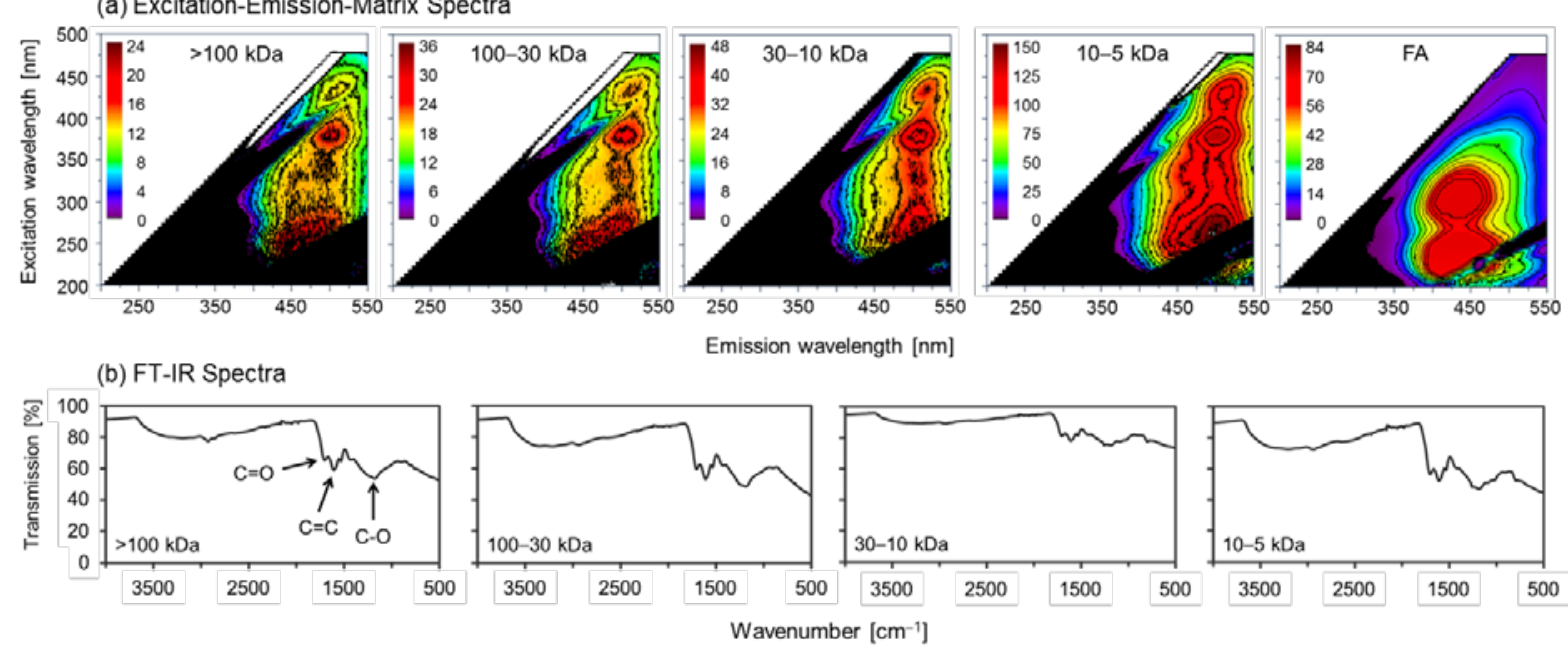

Figure 2: (a) The contour plots of the EEM fluorescence spectra of the HA fractions and the FA; (b) The FT-IR spectra of the HA fractions. 

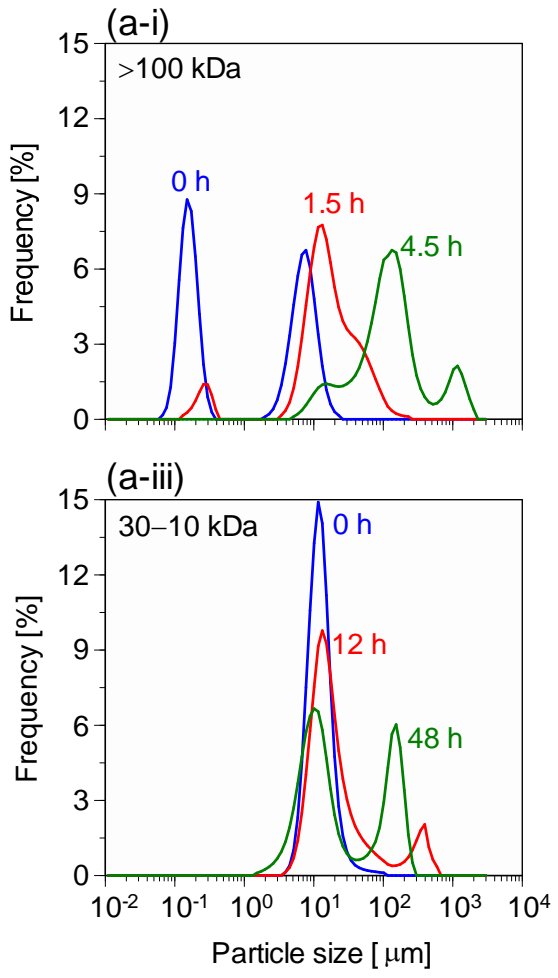

(a-ii)
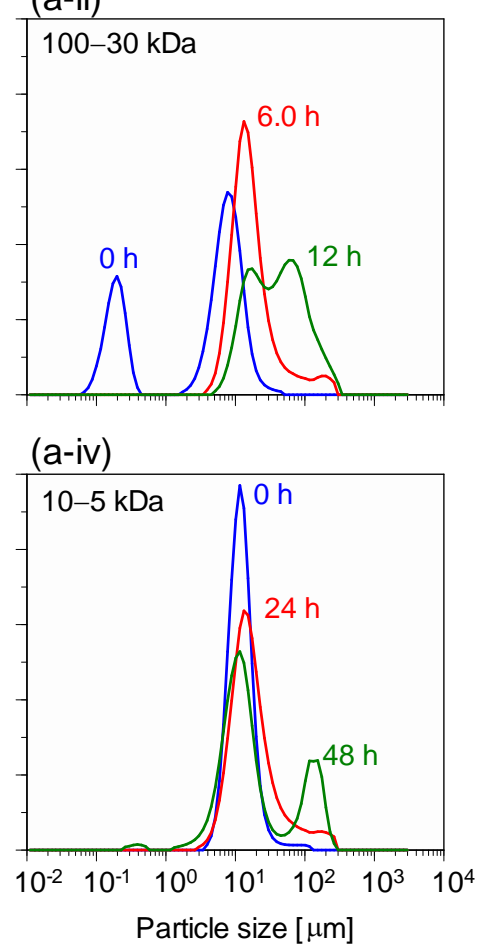

(b)

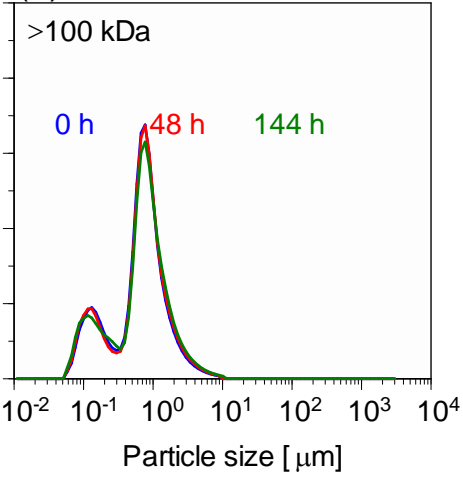

(c)

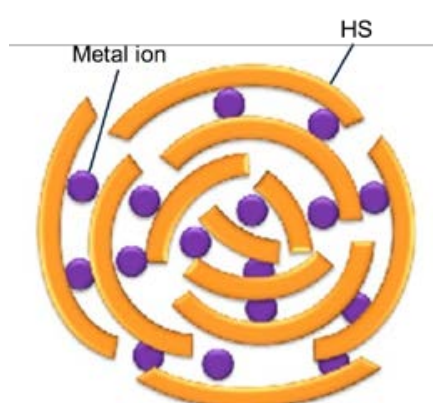

Figure 3: The change in particle size distribution with time of (a) the HA fractions in seawater medium, and (b) the $>100 \mathrm{kDa} H A$ fraction in the purified water medium; (c) a schematic illustration of the onion-like layered structure formation between the HS and metal ions in the aquatic environment. 

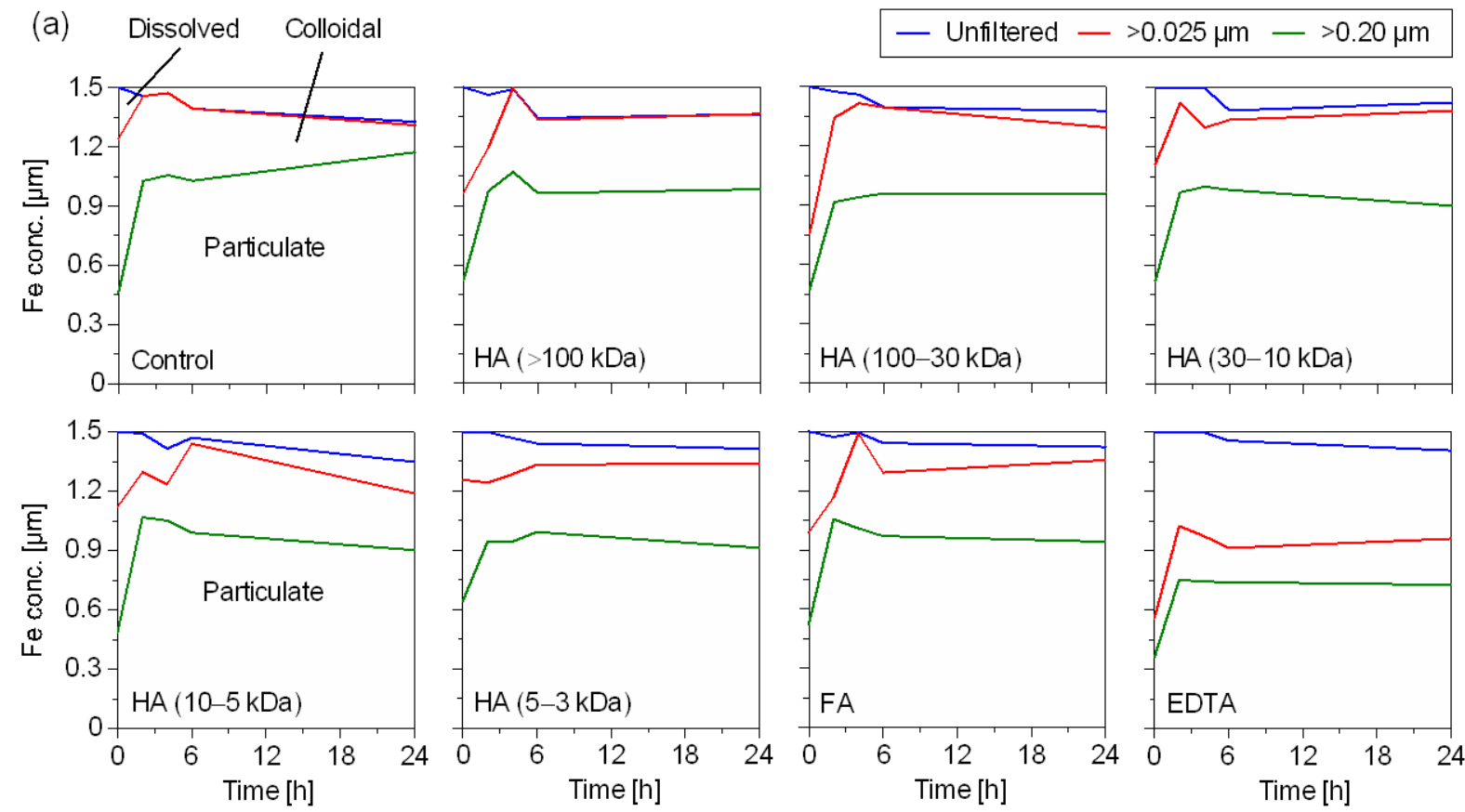

(b)

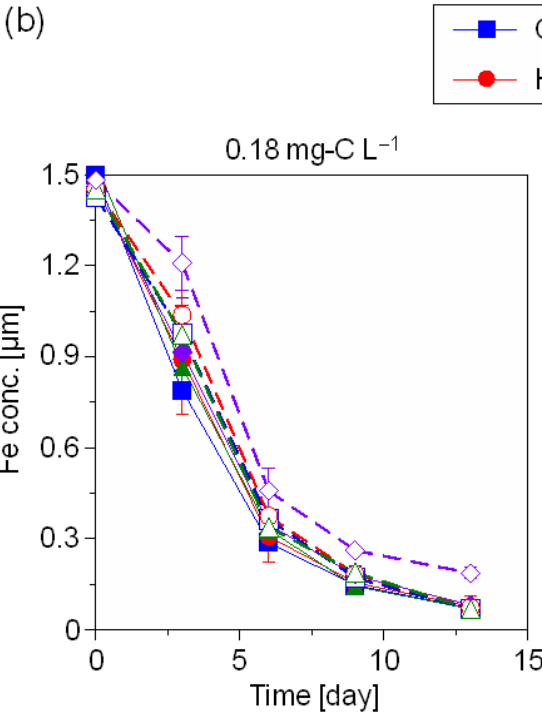

$$
\begin{aligned}
& \text { Control } \rightarrow \mathrm{HA}(100-30 \mathrm{kDa})-\square-\mathrm{HA}(10-5 \mathrm{kDa})-\triangle-\mathrm{FA} \\
& -\mathrm{HA}(>100 \mathrm{kDa}) \longrightarrow \mathrm{HA}(30-10 \mathrm{kDa})-\odot-\mathrm{HA}(5-3 \mathrm{kDa}) \quad \diamond-\text { EDTA }
\end{aligned}
$$
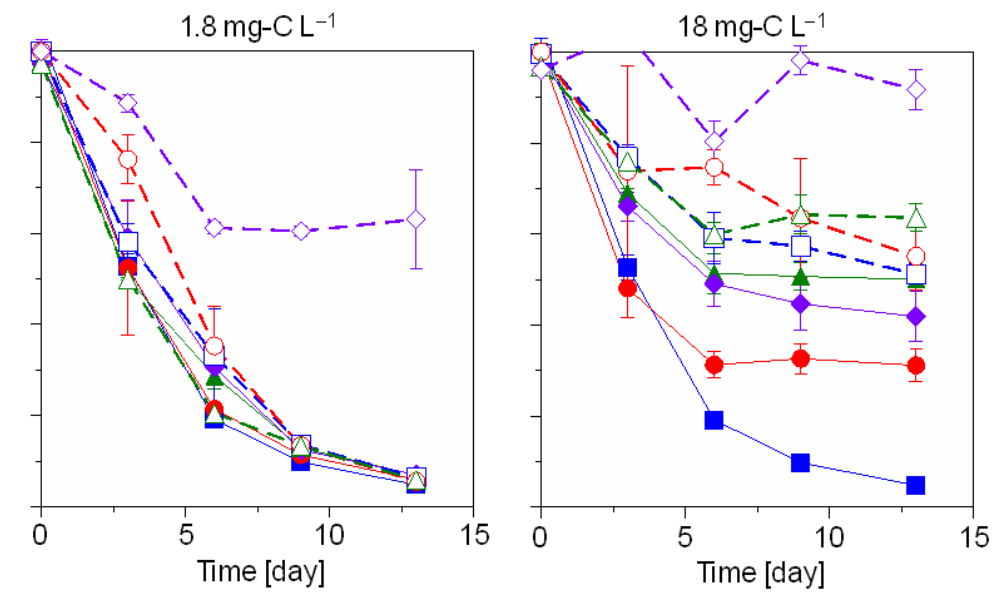

Figure 4: The temporal variations (24 h or 13-day) in the (a) Fe size-speciation and (b) dissolved iron concentrations with respect to the HA fractions, FA and EDTA contents (a. $0.18 \mathrm{mg}-\mathrm{C} \mathrm{L} \mathrm{L}^{-1}$; b. $0.18,1.8$ and $18 \mathrm{mg}-\mathrm{C} \mathrm{L}^{-1}$ ) in seawater medium. The error bars show standard deviation between replicates with $n=3$. 
(a)
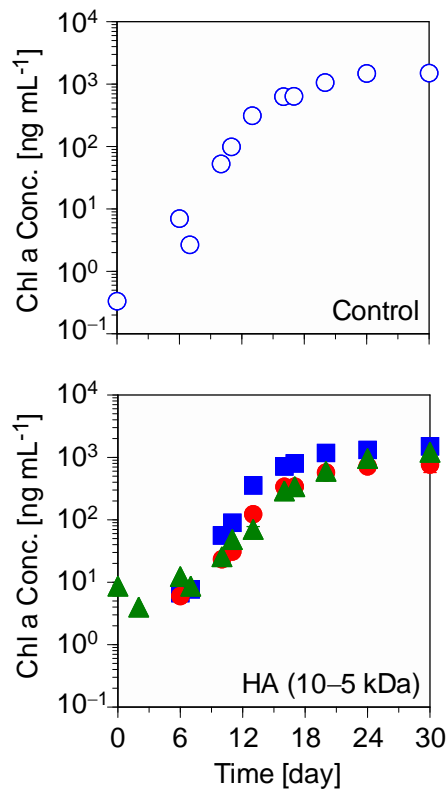

(b)

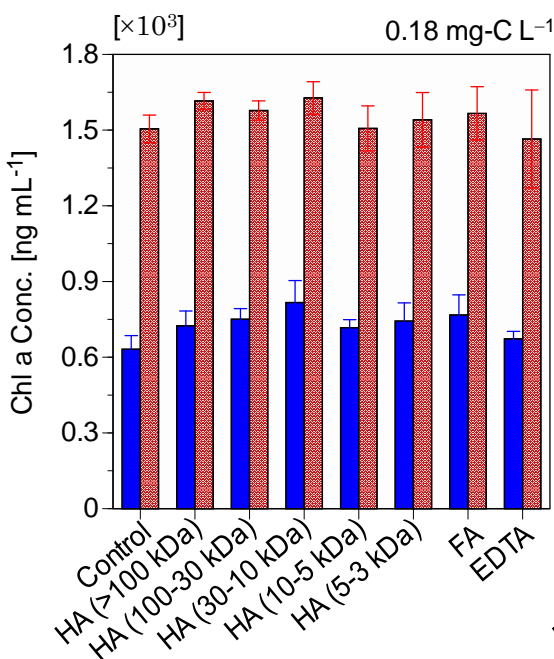

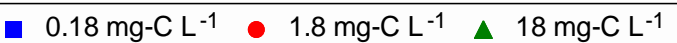
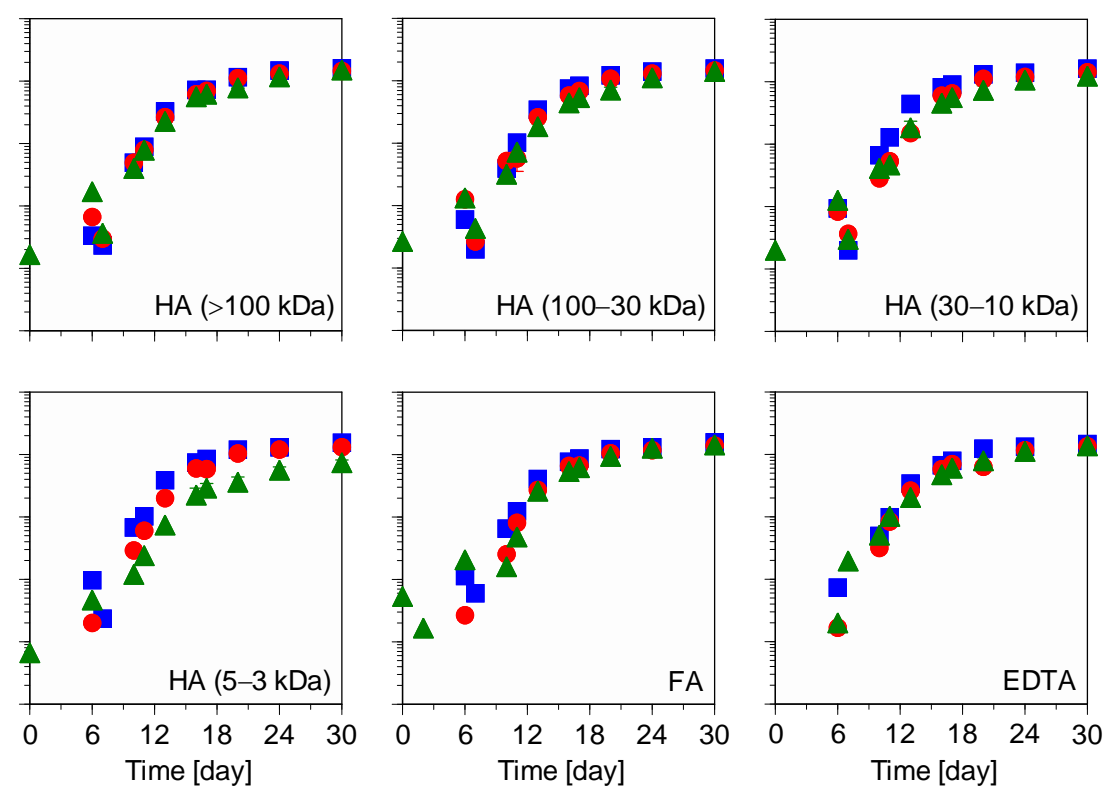

16-day 30-day

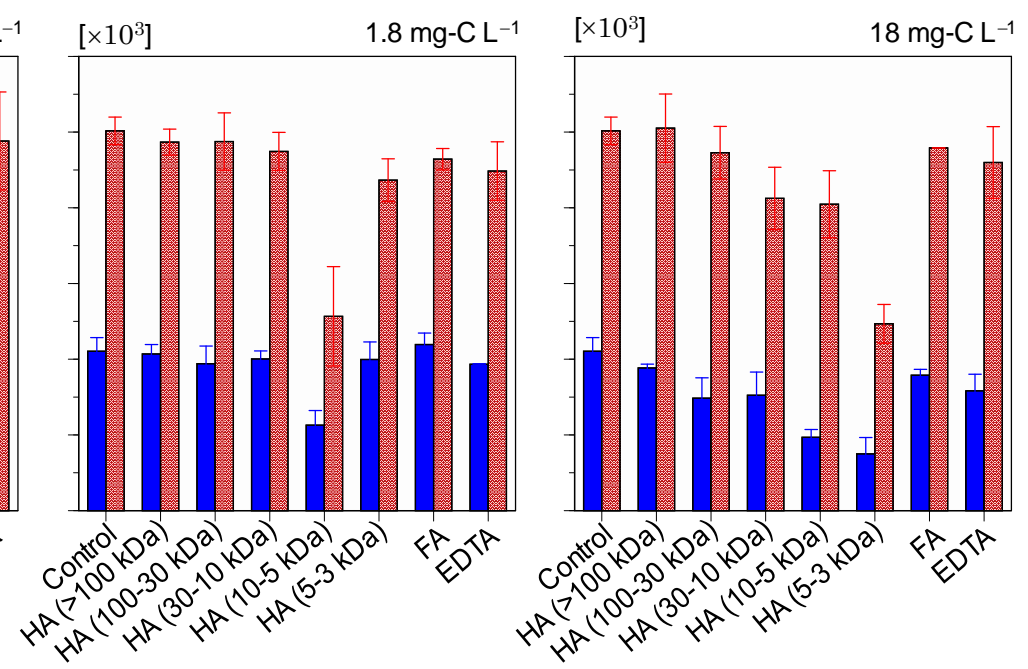

Figure 5: The (a) logarithmic growth rate curve of the phytoplankton ( $P$. parvum), and (b) comparative scenario of the $P$. parvum growth rate (16-day vs 30-day) in terms of the chlorophyll-a (Chl a) concentration with the varying contents $\left(0.18,1.8\right.$ and $\left.18 \mathrm{mg}-\mathrm{C} \mathrm{L}^{-1}\right)$ of the HA fractions, FA and EDTA in the seawater medium. The error bars show standard deviation between replicates with $n=3$. 